\title{
DISTRIBUTION AND ABUNDANCE OF AEROBIC ANOXYGENIC PHOTOTROPHIC BACTERIA IN THE TROPICAL COASTAL WATERS OF GUNUNGKIDUL, YOGYAKARTA
}

\author{
Victor Aprilyanto ${ }^{1}$, Tjut Sugandawaty Djohan², Langkah Sembiring ${ }^{3}$ \\ ${ }^{1}$ Alumnus of Faculty of Biology, Universitas Gadjah Mada, Yogyakarta, Indonesia \\ ${ }^{2}$ Laboratory of Ecology, Faculty of Biology, Universitas Gadjah Mada, \\ Yogyakarta, Indonesia \\ ${ }^{3}$ Laboratory of Microbiology, Faculty of Biology, Universitas Gadjah Mada, \\ Yogyakarta, Indonesia
}

\begin{abstract}
This research was conducted to reveal the distribution and abundance of aerobic anoxygenic phototrophic (AAP) in the tropical coastal waters of Gunungkidul, Yogyakarta. Sampling site was determined at the coastal fish catchment area. We sampled and enumerated total bacterioplankton and AAP bacteria at four sampling depth which are 0, 4, 6, and 20 metre with five replicates each. Several dissolved nutrients such as nitrate, ammonium, phosphate, and sulfate in each respective depths were also measured. Several fluctuations in the nutrient distributions were observed and hypothesized as the regulating factors to the distribution and abundance of AAP bacteria as well as bacterioplankton. The results revealed that AAP bacteria were ranging from $3.83 \times 10^{2}-7.48 \times 10^{2} \mathrm{cell} / \mathrm{ml}$, comprising about $1 \%$ to $2.5 \%$ of total bacterioplankton. The abundance of both community were quite low and showed similar distributions with the nutrients. In conclusion, the distribution and abundance of AAP bacteria were regulated by nutrients as the bottom-up factors and also by predators such as nanoplanktons as the top-down factors.
\end{abstract}

Key words: tropical waters, microbial loop, predation.

ISSN 2413-0877 (C) 2015 The Authors.

Published by KnowledgeE Publishing Services This is an open access article under the CC BY-NC-ND license (http://creativecommons.org/licenses/by-nc-nd/4.0)

Selection and Peer-review under responsibility of the 3rd ICBS-2013

Doi http://dx.doi.org/10.18502/kls.v2i1.150 